
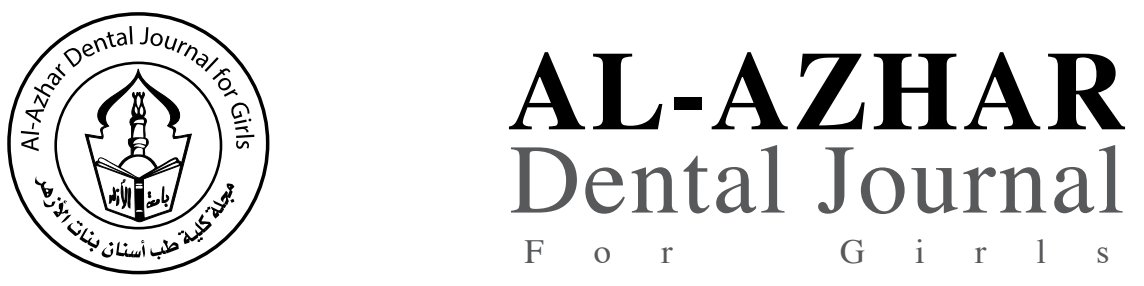

The Official Publication of The Faculty of Dental Medicine For Girls,

Al-Azhar University Cairo, Egypt.

ADJ-for Grils, Vol. 3, No. 2, April (2016) — PP. 153:159

\title{
Influence of Adhesive on Shear Bond Strength Between Denture Base Materials and Self-Cured Silicon Soft Liner
}

\author{
Mohamed I. Ebrahim ${ }^{(1)}$, Mohamed Ashour Ahmed ${ }^{(2)}$, Mostafa I Fayad ${ }^{(3)}$
}

Codex : 10/1604

dentaljournal.forgirls@yahoo.com

\begin{abstract}
Background: Soft lining materials play an important role in modern prosthodontics because of their capability of restoring health of inflamed and distorted mucosa. Gradual changes of oral tissues require that complete or partial dentures be relined to improve their adaptation to the supporting tissue. This study aimed to evaluate the shear bond strength (SBS) of heat cured acrylic and injection-molded Valplast ${ }^{\mathrm{TM}}$ denture base materials to silicone self-cure soft lining materials, with and without adhesive, after storage in two different times in artificial saliva. Materials and Methods: 40 rectangular specimens were prepared from two types of self-cured silicone soft lining material, one with adhesive and the other without adhesive were applied to two types of denture base materials ( heat polymerized Polymethyl methacrylate and injection-molded nylon denture base materials). Shear bond strength of the specimens was measured, after immersion in artificial saliva for different periods ( 72 hours or 10 weeks), using Lloyd universal testing machine. Results: Acrylic denture base bonded to soft liner with adhesive at 72 hours of immersion in artificial saliva showed the highest shear bond strength. Comparing SBS values of the tested soft lining materials revealed significant differences between adhesively bonded and non-adhesively bonded types. Conclusions: This study concluded that the bond strength of the silicone soft lining materials with denture base materials increased with adhesive. Silicone soft lining materials are affected by artificial saliva storage.
\end{abstract}

\section{INTRODUCTION}

A major objective in construction of complete dentures is to attain a denture base that conforms to the supporting tissues with a high degree of accuracy. So, the greater the accuracy of the base, the more stable is the prosthesis and the more the comfortable of the patient. As a result of the changes occurring in the oral tissues under complete or partial dentures, periodic relining of that prosthesis is needed to improve their adaptation to the supporting tissue ${ }^{[1]}$.

Key Words: Dental adhesives, shear strength, soft liner, selfcure acrylic resin

1. Assistant Professor of Dental Biomaterials, Faculty of Dental Medicine Al Azhar University, Cairo (Boys)

2. Assistant Professor of Prosthodontics, Faculty of Dental Medicine, Taif University, Taif, KSA

3. Lecturer of Removable Prosthodontics, Faculty of Dental Medicine, Al- Azhar University. Cairo (Boys) 
Relining is defined as the procedures used to resurface the tissue side of the denture with new base material, thus producing an accurate adaptation to the denture foundation area ${ }^{[2]}$.

Furthermore, Soft liners provide comfort to patients who cannot tolerate occlusal pressure ${ }^{[3]}$. They are often used for management of painful or atrophied mucosa or traumatic ulceration associated with wearing dentures. The soft liner provides comfort for the patient and may reduce residual ridge resorption by reducing impact force in the load bearing areas in the supporting structures during function ${ }^{[4]}$. Polymethyl methacrylate (PMMA) resins have been the most popular denture base resins because of their physical and esthetic properties, accurate fit, stability in oral environment as well as the material's availability, reasonable cost, and ease of manipulation ${ }^{[5,6]}$.

The introduction of injection-molded nylon denture base materials allowed for the control of polymerization process through the flask design. A constant flow of the resin material from the sprue compensates the polymerization shrinkage ${ }^{[7]}$.

The relining material used may be classified as either hard or soft; the selection depends on oral circumstance and treatment planning ${ }^{[8]}$. Soft liners can be either heat-polymerized or auto polymerized ${ }^{[9,10]}$ and they are usually provided as powder and liquid. The powder consists of polymethylmethacrylate (PMMA) and the liquid contain ethyl alcohol (as solvent) and an aromatic ester (di-butyl phthalate) as the plasticizer agent which is responsible for maintaining material softness ${ }^{[11]}$.

Softness is a desirable property of resilient liners. Their optimum thickness has been reported to be approximately 2.5 to $3 \mathrm{~mm}$ to provide good shock absorption ${ }^{[7]}$. One of the common problems with these materials usage is bond failure between the soft liner and the denture base. Any other desirable properties of a denture liner would not be beneficial, unless a good bond to the denture base is achieved. Other problems with soft liners include contamination and accumulation of microorgan- isms, plaque and calculus formation, poor tear and tensile strength ${ }^{[9]}$.

Several studies have been carried out about the effects of water and denture cleansers on the properties of soft lining materials ${ }^{[12]}$. But there are few published articles in regard to the effect of adhesives on the bond strength of denture base to resilient soft liner materials. Therefore, the aim of this study was to evaluate shear bond strength (SBS) of self-cured silicone soft lining material applied to polymethyl methacrylate and injection-molded nylon denture base materials.

\section{MATERIALS AND METHODS}

Specimens were prepared from two chemically different denture base materials

1- Compression-molded Polymethylmethacrylate (Heat cure acrylic, Acrostone (A), AngloEgyptian Company, Batch No.505/04).

2- Injection-molded nylon (Valplast international corp., New York, USA) denture base materials.

Two types of self-cure silicon soft lining material:

a. One with adhesive Bredent [Melliodent, HeraeusKulzer, Berkshire, UK],

b. And, the other one without adhesive [Zetalabor; Zhermack, BadiaPolesine, Rovigo, Italy) were chosen in this study.

\section{Specimens grouping}

As shown in Table (1), specimens of each denture base material were divided into two groups (10 specimens each) according to the type of the bonded soft liner. The first group included denture base material bonded to Zhermack ${ }^{\mathrm{TM}}$ soft liner without adhesive, while the second group included denture base material bonded to Bredent ${ }^{\mathrm{TM}}$ soft liner with adhesive. Then each group was subdivided into 2 subgroups (5 specimens each) according to the period of immersion in artificial saliva before testing of shear bond strength (72 hours and 10 weeks respectively). 
Table (1) Specimens grouping.

\begin{tabular}{|c|c|c|}
\hline Type of denture base material & Groups (10 specimens each) & Subgroups (5 specimens each) \\
\hline \multirow{4}{*}{$\begin{array}{l}\text { Polymethylmethacrylate } \\
\text { (Heat cure acrylic) }\end{array}$} & \multirow{2}{*}{$\begin{array}{l}\text { A: Heat cured acrylic denture } \\
\text { base blocks with soft lining } \\
\text { material without adhesive. }\end{array}$} & $\begin{array}{l}\text { A1: Immersed in artificial saliva for ( } 72) \text { hours for shear } \\
\text { bond strength test. }\end{array}$ \\
\hline & & $\begin{array}{l}\text { A2: Immersed in artificial saliva for (10) weeks for shear } \\
\text { bond strength test. }\end{array}$ \\
\hline & \multirow{2}{*}{$\begin{array}{l}\text { B: Heat cured acrylic denture } \\
\text { base blocks with soft lining } \\
\text { material with adhesive. }\end{array}$} & $\begin{array}{l}\text { B1: Immersed in artificial saliva for ( } 72) \text { hours for shear } \\
\text { bond strength test. }\end{array}$ \\
\hline & & $\begin{array}{l}\text { B2: Immersed in artificial saliva for (10) weeks for shear } \\
\text { bond strength test. }\end{array}$ \\
\hline \multirow{4}{*}{ Injection-molded nylon } & \multirow{2}{*}{$\begin{array}{l}\text { C: Injection-molded nylon } \\
\text { blocks with soft lining } \\
\text { material without adhesive. }\end{array}$} & $\begin{array}{l}\text { C1: Immersed in artificial saliva for ( } 72) \text { hours for shear } \\
\text { bond strength test. }\end{array}$ \\
\hline & & $\begin{array}{l}\text { C2: Immersed in artificial saliva for (10) weeks for shear } \\
\text { bond strength test. }\end{array}$ \\
\hline & \multirow{2}{*}{$\begin{array}{l}\text { D: Injection-molded nylon } \\
\text { blocks with soft lining } \\
\text { material with adhesive. }\end{array}$} & $\begin{array}{l}\text { D1: Immersed in artificial saliva for (72) hours for shear } \\
\text { bond strength test. }\end{array}$ \\
\hline & & $\begin{array}{l}\text { D2: Immersed in artificial saliva for (10) weeks for shear } \\
\text { bond strength test. }\end{array}$ \\
\hline Total & & 40 \\
\hline
\end{tabular}

\section{Preparation of artificial saliva:}

The artificial saliva composition used in this study conformed to that described by Fusayama et al. ${ }^{[13-17]}$ and the recipe is presented in Table 2. The chemical reagents were added to the solutions in the order they are listed.

\section{Preparation of Specimens for shear Bond Strength (SBS) testing}

\section{Fabrication of Specimens:}

Shear adhesive strength was evaluated using a simple overlap-joint model. Stainless steel dies $(50 \times 10 \times 3 \mathrm{~mm})$ were machined to prepare standardized resin blocks (Heat cure acrylic and Injectionmolded nylon). Stainless steel dies (spacer for resilient liner) measuring $(10 \times 10 \times 3 \mathrm{~mm})$ were prepared as spacers to ensure uniformity of the soft liner being tested (Fig 1).

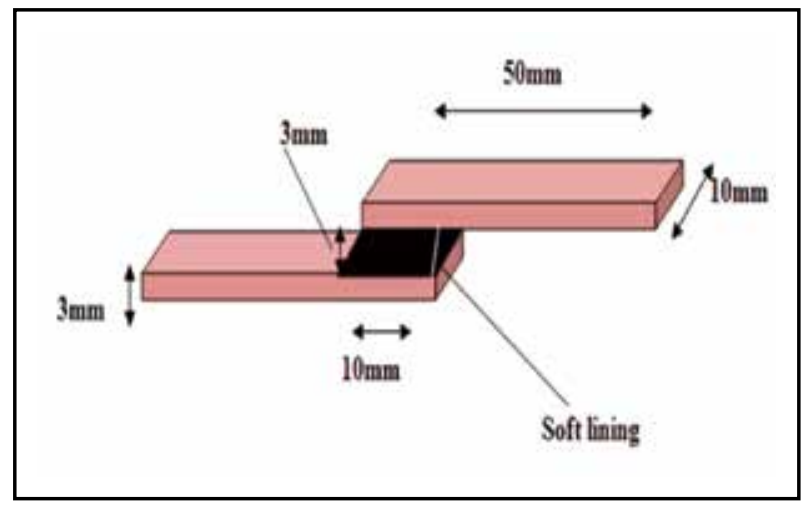

Fig. (1) Specimen configuration

Impressions of the Stainless steel dies were made in polyether putty (Impregum Penta Putty, 3M ESPE, Germany) material to fabricate resin blocks. Molten wax (Hindustan Modelling Wax, India) was poured in the mold obtained from the dies. The wax blocks were allowed to cool, harden and subsequently to be invested in dental stone in 
a dental flask. After the dewaxing procedures, the acrylic resin was packed into the mold space and processed at $75{ }^{\circ} \mathrm{C}$ for $1.5 \mathrm{~h}$, followed by $100^{\circ} \mathrm{C}$ for $1 \mathrm{~h}$. After deflasking procedures, all the polymerized acrylic samples were finished and polished leaving the testing surface. They were then ultrasonically cleaned with distilled water and dried with compressed air to remove the surface impurities. The dies for resin blocks and spacer were invested in laboratory polyether rubber to provide uniform space for lining material and for easy removal of the processed samples.

Table (2) Chemical reagents for preparation of artificial saliva

\begin{tabular}{|c|c|}
\hline Reagent & Amount $(\mathrm{g} / \mathrm{l})$ \\
\hline $\mathrm{NaCl}$ & 0.40 \\
\hline $\mathrm{CaCl}_{2} 2 \mathrm{H}_{2} \mathrm{O}$ & 0.79 \\
\hline $\mathrm{KCl}$ & 0.40 \\
\hline $\mathrm{Na}_{2}{\mathrm{~S} 9 \mathrm{H}_{2} \mathrm{O}}$ & 0.005 \\
\hline $\mathrm{NaH}_{2} \mathrm{PO}_{4} \mathrm{H}_{2} \mathrm{O}$ & 0.78 \\
\hline Urea-CO $\left(\mathrm{NH}_{2}\right)_{2}$ & 1.00 \\
\hline Distilled water & $1000 \mathrm{ml}$ \\
\hline
\end{tabular}

\section{Packing of the Denture Lining Material}

According to the manufacturer's instructions, the application of Bredent ${ }^{\mathrm{TM}}$ was preceded by 1 min. application of the supplied primer, while for the other liner brand (Zhermack $\left.{ }^{\mathrm{TM}}\right)$, this step was absent. Equal lengths of base and catalyst of soft liner was mixed for $30 \mathrm{sec}$. Lining the polymerized resin blocks with auto-polymerizing silicone soft denture liner was done after removing the Stainless steel spacer and allowed to polymerize for $10 \mathrm{~min}$.

After polymerization all the specimens were recovered and excess liner flash was cut using sharp blade. Thus the final specimens were obtained with soft liner overlap between two resin blocks. The specimens were then immersed in artificial saliva for (72) hours and (10) weeks for shear bond strength test.

\section{Shear bond Strength testing}

Shear bond testing was done using Lloyd universal testing machine (model LRX plus II. Fareham, England). Testing Specimens for shear bond strength, all the specimens were aligned in Universal testing machine with one end of acrylic specimen attached to upper clamp and another end of acrylic specimen to the lower clamp. The specimen was pulled with a crosshead speed of $5 \mathrm{~mm} / \mathrm{min}$. All the specimens were placed under tension until failure in the specimen occurred. The liner was separated from acrylic resin specimen by pulling of clamps in opposing directions. The maximum shear stress before failure was recorded for each specimen. The peak load applied was recorded in chart recorder.

Paired t-test was performed using the Statistical Package for Social Sciences (version 17, SPSS) to determine if any statistical significant difference exists between groups. All statistical analyses were considered significant at the $\mathrm{P}$ value $<0.05$ level.

\section{RESULTS}

Means and standard deviations obtained from the shear test are shown in (Table 3). Group B1 (acrylic denture base bonded to Bredent ${ }^{\mathrm{TM}}$ soft liner with adhesive at 72 hours of immersion in artificial saliva ) showed the highest mean shear bond strength value (2.45), while the lowest mean value was recorded for group A2 (acrylic denture base bonded to Bredent ${ }^{\mathrm{TM}}$ soft liner with adhesive at 10 weeks of immersion in artificial saliva).

Descriptive statistical values and comparisons between the heat cured acrylic and injection-molded nylon are shown in (Table 4).

Significant differences were recorded between SBS values of all groups $(\mathrm{P}<0.05)$ except groups $\mathrm{A} 1$ and $\mathrm{C} 1$. Comparing SBS values of different types of soft lining materials (Table 5) revealed significant differences among all groups $(\mathrm{P}<0.05)$ except $\mathrm{C} 2$ and D2. The effect of immersion time in artificial saliva was analyzed as shown in (Table 6). The re- 


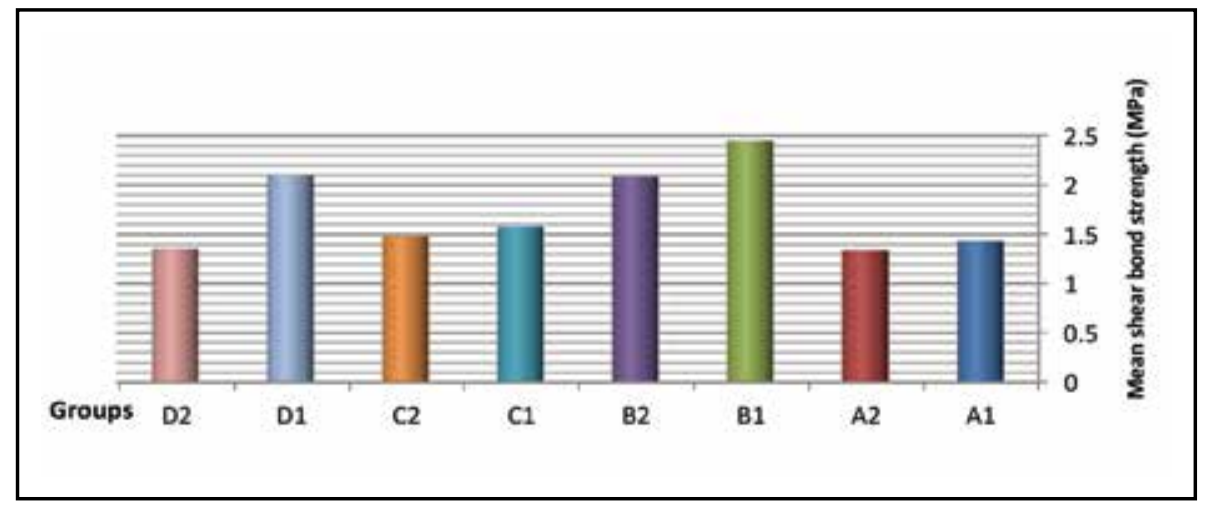

Fig. (2) Mean shear bond strength of all groups.

sults showed a significant difference only between groups D1 and D2 $(\mathrm{P}<0.05)$.

Table (3) Shear Bond Strength Results (in MPa) for all groups.

\begin{tabular}{|c|c|c|}
\hline Groups & Mean & Std. Deviation \\
\hline A1 & 1.43 & .064 \\
\hline A2 & 1.34 & .050 \\
\hline B1 & 2.45 & .048 \\
\hline B2 & 2.09 & .222 \\
\hline C1 & 1.58 & .186 \\
\hline C2 & 1.48 & .046 \\
\hline D1 & 2.10 & .035 \\
\hline D2 & 1.35 & .102 \\
\hline
\end{tabular}

Table (4) Comparison between SBS values of different types of denture base materials

\begin{tabular}{|c|c|c|}
\hline Groups & Std. Deviation & P-value \\
\hline A1 - C1 & 0.16460 & 0.152 \\
\hline A2 -C2 & 0.07767 & $0.033^{*}$ \\
\hline B1- D1 & 0.05447 & $0.001^{* *}$ \\
\hline B2 - D2 & 0.13475 & $0.002^{* *}$ \\
\hline
\end{tabular}

Table (5) Comparison between SBS values of different types of soft lining materials

\begin{tabular}{|c|c|c|}
\hline Groups & Std. Deviation & P- value \\
\hline A1 - B1 & 0.09215 & $0.000^{* *}$ \\
\hline A2 - B2 & 0.22136 & $0.006^{* *}$ \\
\hline C1 - D1 & 0.21000 & $0.016^{*}$ \\
\hline C2 - D2 & 0.14773 & 0.196 \\
\hline
\end{tabular}

Table (6) Comparison between SBS values of different times of immersion in artificial saliva

\begin{tabular}{|c|c|c|}
\hline Groups & Std. Deviation & P-value \\
\hline A1 - A2 & 0.07416 & 0.083 \\
\hline B1 - B2 & 0.24391 & 0.063 \\
\hline C1 - C2 & 0.20903 & 0.379 \\
\hline D1 - D2 & 0.13675 & $0.002 * *$ \\
\hline
\end{tabular}

\section{DISCUSSION}

Studies have questioned the causes of interfacial stress distribution of liners bonded to acrylic substrates ${ }^{[18,19]}$. Many tests have been used to simulate clinical stresses that affect the bond integrity between the two materials. Tensile test has been questioned in simulating the clinical 
situation $^{[20]}$. However, the interpretation of the shear studies is difficult since different configuration are available in shear testing, and the test devices need improvements on the way of applying the load on the specimen ${ }^{[21]}$. In addition to that, the conventional shear tests still have highlighted that tensile stress distribution is sometimes higher than the shear stress itself ${ }^{[22]}$.

It is important to measure the adhesive bond instead of the cohesive strength of resilient liners to assess interfacial separation under oral conditions. Otherwise, cohesive rupture of their soft liner give only limited information on the strength of the liner material ${ }^{(23)}$.

In the present study, the shear bond strength for the two types of denture base material were tested at (72 hours) and (10 weeks) after different types of soft lining materials application. The effects of soft lining materials type and artificial saliva storage on shear bond strength were tested.

Comparing the results showed that shear bond strength of the heat cure acrylic denture base material with prime was greater than that of injection-molded nylon denture base material. This could be the result of the difference in the nature of the bond between the soft lining materials and the two types of denture base materials ${ }^{(24)}$.

An adhesive is supplied to aid in bonding to denture base resin because silicone soft liner has little or no chemical adhesion to Polymethylmethacrylate denture base resin ${ }^{(25)}$.

The present results showed a decrease in mean values of bond strength of the all types of denture base when specimens were immersed in artificial saliva, the pure silicone rubber has very low water sorption and solubility but it has been suggested that fillers and impurities presented besides inter molecular spaces are responsible for water sorption and solubility ${ }^{(26)}$.
The sorption and solubility values which were very low due to the high cross linking nature of the soft lining materials ${ }^{(27)}$, besides silicone soft lining materials shows very low level of microleakage at the bond liner/denture base surface; so the material was highly affected by artificial saliva storage. But this will lead to stresses concentration at the sharp edges of materials in which the stresses were applied ${ }^{(26)}$, this causing decrease in the mean values of bond strength of the soft lining materials. The most common reason for the failure of dentures lined with a silicone-based soft lining material is the failure of adhesion between the denture base and soft lining materials.

In a clinical setting, adhesive failure is initially observed at the edge of the denture border region as cracks involving localized unhygienic debris, and it usually spreads inside a denture with time. The stress occurs between the bonding surfaces when the soft lining material absorbs water. Thus, it is conceivable the adhesive failure starts from the edge of the denture because the edge can be immersed in saliva more easily. In addition to these facts, the recorded failure strength value and the mode of specimen failure were affected by the type of the test method such as peel, tensile and shear tests ${ }^{(12)}$.

\section{CONCLUSION}

On the basis of the current study, it was concluded that:

- All of the tested lining materials were acceptable for clinical use.

- There were statistically significant differences among the studied denture base materials.

- Adhesives increase the bond strength of the silicone soft lining materials with denture base materials.

- Silicone soft lining materials are affected by artificial saliva storage. 


\section{REFERENCES}

1. Anil N, Canan H. Microleakage study of various soft denture liners by autoradiography Effect of accelerated aging. J Prosthet Dent 2000; 84: 394-9.

2. Carrick T, Kamohara H, Cabe J. Adhesive bond strength and compliance for denture soft lining materials. J Biomaterials 2002; 23:1347-1352.

3. Jacobsen N, Mitchell D, Johnson D, Holt R.Lased and sandblasted denture base surface preparations affecting resilient liner bonding. JProsthet Dent 1997; 78:153-8.

4. Kawano F, Dootz E, Koran A, Carig R. Sorptionand solubility of 12 soft denture liners. J Prosthet Dent1994; 72(4): 393-8.

5. Anusavice K, Phillips R. Phillip's science of dentalmaterials. 11th ed. Philadelphia: W B Sauders Co.; 2003.

6. Nejatian, T., Johnson, A. and Van Noort, R. Reinforcement of Denture Base Resin. Advances in Science andTechnology, 2006;49:124-29.

7. Kunwarjeet $\mathrm{S}$ and Nidhi G. Injection molding technique for fabrication of flexible prosthesis from flexible thermoplastic denture base material. World J Dent2012; 3:303-7.

8. Moffitt A, Woody R, Parel S, Miller B. Failuremodes with point loading of three commerciallyavailable denture teeth. J Prosthodont 2008; 17:432-8.

9. Pinto J, Mesquita M, Henriques G, Arruda M. Effect of thermocycling on bond strength and elasticity of 4 longterm soft denture liners. J Prosthet Dent2002; 88: 516-521.

10. Yanikoglu N, Denizoglu S. The effect of different solutions on the bond strength of soft lining materials to acrylic resin. Dent Mater J 2006; 25: 39-44.

11. Singh K, Chand P, Singh B, Patel C. Study of the effect of surface treatment on the long term effectiveness of tissue conditioner. J Oral Sci 2010; 52: 261-265.

12. Mese A, Guzel K. Effect of storage duration on the hardness and tensile bond strength of silicone- and acrylic resin-based resilient denture liners to a processed denture base acrylic resin. J Prosthet Dent 2008; 99:153-159.

13. Mareci D, Chelariu R, Dan I, GordinD, Gloriant T. Corrosion behavior of $\beta$-Ti20Mo alloy in artificial saliva. J Mater Sci. 21 2010;21:2907-13.

14. Sharma M, Kumar A, Singh N, Adya N, Saluja B. Electrochemical Corrosion Behavior of Dental/Implant
Alloys in Artificial Saliva. J Mater Eng Perform 2008; 17:695-01.

15. Schiff N, Grosgogeata B, Lissaca M, Dalard F. Influence of fluoride content and $\mathrm{pH}$ on the corrosion resistance of titanium and its alloys. Biomater J 2002;23:1995-02.

16. Shim H, Oh K, Woo J, HwangC,Kim K. Corrosion resistance of titanium-silver alloys in an artificial saliva containing fluoride ions. J Biomed MaterRes 2005;73:252-9.

17. Han S, Quick D. Nickel-titanium spring properties in a simulated oral environment. Angle Orthod 1993; 63: 67-2.

18. Hatamleh M, Watts D. Bonding of maxillofacial silicone elastomers to an acrylic substrate. Dent Mater 2010;26:387-95.

19. Hayakawa I, Keh E, Morizawa M, Muraoka G, Hirano S. A new polyisoprene-based light-curing denture soft lining material. J Dent 2003;31:269-74.

20. Mese A, Guzel K, Uysal E. Effect of storage duration on tensile bond strength of acrylic or silicone-based soft denture liners to a processed denture base polymer. ActaOdontolScand 2005;63:31-5.

21. Pecora N, Yaman P, Dennison J, Herrero A. Comparison of shear bond strength relative to two testing devices. J Prosthet Dent 2002;88:511-5.

22. Placido E, Meira J, Lima R, Muench A, Souza R, Ballester R. Shear versus micro-shear bond strength test: a finite element stress analysis. Dent Mater 2007;23:1086-92.

23. Kulak-Ozkan Y, Sertgos A, Gedik H. Effect ofthermocycling on tensile bond strength of six siliconesbased, resilient denture liners. J Prosthet Dent 2003;89: 303-10.

24. Meng G, Chung K, Fletcher-Stark M, Zhang H. Effect of surface treatments and cyclic loading on the bond strength of acrylic resin denture teeth with auto polymerized repair acrylic resin. J Prosthet Dent 2010; 103: 245-52.

25. MarraJ,Paleari A, Pero A, Souza R, Barbosa D,Compagnoni M. Effect of methyl methacrylatemonomer on bond strength of denture base resin toacrylic teeth. Int $\mathrm{J}$ Adhesion \& Adhesives 2009;29:391-5.

26. Hadary A, Drummond J. Comparative study ofwater sorption, solubility, and tensile bond strength oftwo soft lining materials. Prosthet Dent 2000; 83:356-61.

27. Aydin A, Terzioglu H, Akinay A, UlubayramK,Hasirci N. Bond strength and failure analysis of liningmaterials to denture resin. Dent Mater J 1999; 15:211-8. 